\title{
ASB2 wt Allele
}

National Cancer Institute

\section{Source}

National Cancer Institute. ASB2 wt Allele. NCI Thesaurus. Code C132168.

Human ASB2 wild-type allele is located in the vicinity of $14 q 32.12$ and is approximately 43

$\mathrm{kb}$ in length. This allele, which encodes ankyrin repeat and SOCS box protein 2, plays a role in promoting the ubiquitination of substrate proteins. 